their use causes the cardiac output to increase by reducing the resistance to ventricular ejection. Vasodilator drugs have extremely potent cardiovascular effects, however, and patients who are acutely ill need haemodynamic monitoring to derive the greatest benefit from this form of treatment. In a small but important group of patients with low-output states complicating myocardial infarction the left atrial pressure is normal or even low. ${ }^{12}$ Again, measurement of the pulmonary artery enddiastolic pressure is necessary to identify these patients, who usually respond well to expansion of the plasma volume.

Applying these principles, then, will facilitate the management of patients with acute haemodynamic disorders. In small groups of patients there has also been evidence that this approach may improve survival rates, at least in the short term ${ }^{13} 14$ - a possibility that calls for further study.

1 Armstrong PW, Baigrie RS. Hemodynamic monitoring in the critically ill patient : overview of symposium. Can Med Assoc F 1979;121:865-6.

2 Braunwald E, Frahm CJ, Ross J Jr. Studies on Starling's law of the heart. V Left ventricular function in Man. F Clin Invest 1961;40:1882-90.

3 Bishop VS, Stone HL, Guyton AC. Cardiac function curves in conscious dogs. Am $\mathcal{F}$ Physiol 1964 ;207:677-82.

4 Berglund E. Ventricular function VI. Balance of left and right ventricular output: relation between left and right atrial pressures. Am $\mathcal{F}$ Physiol 1954;178:381-6

5 Cohn JN, Tristani FE, Khatri IM. Studies in clinical shock and hypotension VI. Relationship between left and right ventricular function. f Clin Invest 1969;48:2008-18.

6 Forrester JS, Diamond G, McHugh TJ, Swan HJC. Filling pressures in the right and left sides of the heart in acute myocardial infarction. A reappraisal of central venous pressure monitoring. N Engl f Med 1971; 285:190-3.

7 Swan HJC, Ganz W, Forrester JS, Marcus H, Diamond G, Chonette D. Catheterization of the heart in man with use of flow-directed balloontipped catheter. $N$ Engl $\mathcal{F}$ Med $1970 ; 283: 447-51$.

8 Jenkins BS, Bradley RD, Branthwaite MA. Evaluation of pulmonary arterial end-diastolic pressure as an indirect measure of left atrial mean pressure. Circulation 1970;42:75-8.

- Crexells C, Chatterjee K, Forrester JS, Dikshit K, Swan HJC. Optimal level of filling pressure in the left side of the heart in acute myocardial infarction. $N$ Engl f Med 1973 ;289:1263-6.

${ }^{10}$ Delgado CE, Pitt B, Taylor DR, Weisfeldt ML, Kelly DT. Role of sublingual nitroglycerin in patients with acute myocardial infarction. Br Heart f 1975 ;37:392-6.

11 Chatterjee K, Parmley WW, Ganz W, et al. Hemodynamic and metabolic responses to vasodilator therapy in acute myocardial infarction. Circulation $1973 ; 48: 1183-93$.

12 Forrester JS, Diamond G, Chatterjee K, Swan HJC. Medical therapy of acute myocardial infarction by application of hemodynamic subsets. $N$ Engl f Med 1976 ;295:1404-13.

13 Chatteriee K, Swan HJC, Kaushik VS, Joblin G, Magnusson P, Forrester JS. Effect of vasodilator therapy for severe pump failure in acute myocardial infarction on short-term and late prognosis. Circulation $1976 ; 53: 797-802$.

14 Fowler MB, Timmis AD, Chamberlain DA. Synergistic effects of a combined salbutamol-nitroprusside regimen in acute myocardial infarction and severe left ventricular failure. $\mathrm{Br}$ Med $\mathcal{F}$ 1980; 280:435-7.

\section{Early diagnosis of carcinoma of the prostate}

The quest for early diagnosis in any condition is founded on the belief that intervention at that stage will produce a higher survival rate and better quality of life for the patient. The degree to which treatment influences prognosis in early carcinoma of the prostate is still, however, uncertain-as is the form it should take: radical surgery, orchidectomy, hormonal therapy, and radiotherapy all have their champions.

Because of this uncertainty a Medical Research Council trial has been set up to evaluate the place of radiotherapy in the treatment of early $\left(T_{0}\right.$ and $\left.T_{1}\right)$ prostatic tumours without metastases; a further MRC trial is to compare orchidectomy, radiotherapy, and a combination of both in the treatment of larger $\left(T_{2}, T_{3}\right.$, and $\left.T_{4}\right)$ prostatic tumours without metastases. There is, however, a growing body of opinion that early carcinoma of prostate may be cured by either radical surgery or radiotherapy. The effect of treatment on survival is particularly difficult to assess in carcinoma of prostate, which may be undiagnosed in so many cases. The increased effectiveness of modern diagnosis may be uncovering patients with an excellent prognosis, so creating a spurious impression of improved survival. Carefully controlled clinical trials are needed to resolve the uncertainties ${ }^{1}$; but meanwhile every effort should be made to establish the diagnosis as soon as possible, and for that reason some new biochemical approaches are provoking wide interest.

The time-honoured reliance by the clinician on digital palpation of the prostate has become unsatisfactory as radical methods of treatment have made precise diagnosis mandatory. The cornerstone of accurate diagnosis lies in histological examination. The needle biopsy, which can be performed so effectively with the Tru-cut needle by the transrectal or transperineal route, allows accurate diagnosis and even a small nodule can be precisely sampled. Less satisfactory is the aspiration biopsy, ${ }^{2}$ which provides only a cytological sample; diagnosis is less reliable, as interpretation can be difficult even for a skilled cytologist.

Even more unreliable are biochemical aids such as estimation of the acid phosphatase, in particular its tartrate labile form, sometimes termed the "prostatic" component. High values certainly indicate the presence of bony metastases, but the concentration is frequently normal when disease is confined to the prostate, and technetium bone scans have shown that bony metastases are often present in patients with normal bone radiographs and normal concentrations of acid phosphatase. ${ }^{3}$ In a comparison of three enzymic methods of estimation with a double antibody radioimmunoassay, ${ }^{3}$ the latter gave more positive results but yielded high values in only $8 \%$ of the patients with intracapsular disease with no metastases. False-positive results can also occur, though the longstanding belief that prostatic digital examination raised the phosphatase concentration even in the normal patient has been largely discredited. ${ }^{4}$

A screening test for early malignant change in the prostate has long been sought, and a possible basis is the recognised biochemical phenomenon of a lower zinc concentration in malignant prostatic tissue than in benign hypertrophy or in the normal gland. ${ }^{5}$ Another discriminant is the amount of testosterone in prostatic tissue; concentrations are higher in carcinoma of the prostate than in benign hypertrophy. ${ }^{\circ}$ Habid $e l a l^{7}$ have recently suggested that estimating the zinc and hormone concentrations may provide a reliable test for distinguishing between benign and malignant disease in the prostate. Any change in the zinc content of the gland, however, is likely to result from the development of a frank carcinoma and not to precede it. No one has yet shown a change in zinc content except as a result of a longstanding tumour. Habid and his co-workers used transurethral resection specimens, and in as many as $20 \%$ of resections these yield benign tissue even when a definite neoplasm exists in the periphery of the gland. Clearly, therefore, if the prostatic zinc content is found to be low even when carcinoma is confined to the periphery of the gland this change could be a valuable marker. Reduced zinc concentrations have been reported in the leucocytes of patients with liver disease, ${ }^{8}$ but whether any similar alteration occurs in prostatic disease is not yet known. 
The idea that a change that is common to all malignant cells may occur at the plasma membrane has stimulated another line of work. Bowen and Kulatilake ${ }^{9}$ have examined the plasma membrane of cells prepared from tissue obtained by transurethral prostatic resection; and, though their results were not clear cut, a sharply defined protein peak was found in isoelectric focusing gels in all samples of histologically proved carcinoma of the prostate. Work is continuing to see whether this test may help to resolve doubts when atypical prostatic glands are present but no definite carcinoma is found.

As yet, therefore, the quest for a biochemical screening test for early prostatic cancer is not completed, and diagnosis has to be based on histological examination. A biochemical answer, however, may not be far away; and ideally it should be based on a non-invasive technique. Among the most promising possibilities is the measurement of zinc concentrations in seminal fluid or leucocytes.

1 Trasti H, Nilsson S, Peterson L-E. Applied diagnostic techniques: a decisive factor in the long-term $\mathrm{T}$-year survival rate in prostatic carcinoma. Br $\mathcal{F}$ Urol 1979;51:135-9.

2 Franzen S, Giertz G, Zajicek J. Cytological diagnosis of prostatic tumours by transrectal aspiration biopsy: a preliminary report. $\mathrm{Br} \mathcal{F}$ Urol 1960;32:193-6.

3 Bruce AW, Mahan DE, Morales A, Clark AF, Belville WD. An objective look at acid phosphatase determinations. Br F Urol 1979;51:213-7.

- Johnson CD, Costa D, Castro JE. Acid phosphatase after examination of the prostate. Br $\mathcal{F}$ Urol 1979;51:218-23.

- Gyorkey G, Min KW, Huff JA, Hyorkey P. Zinc and magnesium in human prostate gland; normal, hyperplastic and neoplastic. Cancer Res $1967 ; 27: 1348-53$.

- Habib FK, Lee IR, Stitch SR, Smith PH. Androgen levels in the plasma and prostatic tissues of patients with benign hypertrophy and carcinoma of the prostate. F Endocrinol 1976;71:99-107.

${ }^{7}$ Habib FM, Mason MK, Smith PH, Stitch SR. Cancer of the prostate: early diagnosis by zinc and hormone analysis? Br $\mathcal{F}$ Cancer 1979;39: 700-4.

${ }^{8}$ Keeling PWN, Thompson RPH, Jones R, Hilton PJ. Zinc deficiency in liver disease. Gut 1979;20:A954.

- Bowen JG, Kulatilake AE. A common marker for cancer cells ? Br f Cancer $1979 ; 40: 806-8$.

\section{Female sterilisation-no more tubal coagulation}

Presentations at the recent Tokyo IXth World Congress of Gynaecology and Obstetrics on female sterilisation emphasised the use of occlusive devices rather than thermocoagulation-a welcome trend. In retrospect laparoscopy may now be seen as having had both beneficial and deleterious effects on developing methods of sterilisation. Previously, gynaecologists had occluded the Fallopian tubes by the abdominal or vaginal approach using suture material (with a Pomeroy type procedure chromic catgut was the most popular), but different techniques were needed for laparoscopic sterilisation. Despite the accumulation of reports of adverse consequences, including burns of the abdominal wall and the bowel, and of pregnancy rates higher than with alternative procedures, relatively uncontrolled unipolar electrocoagulation is still used, even in some teaching centres, in Britain. ${ }^{1}$ Requests by patients for reversal of sterilisation are now focusing attention on the extraordinarily destructive effect of this procedure: Winston reported that tubal reconstruction was possible in only $37 \%$ of women treated by unipolar cautery and the pregnancy rate overall was a depressing $17 \% .^{2}$

Bipolar cautery is safer and more controlled than unipolar coagulation, but is still unnecessarily destructive, especially when coagulation is used at more than one site along the tube. The newer means of occluding the tube by plastic and silicone clips and rings seem to give fewer complications and less tissue destruction, with similar pregnancy rates. ${ }^{3}$ Clips need to be placed at the isthmus, preferably $1.0-1.5 \mathrm{~cm}$ from the cornu, so allowing a reversal operation to be carried out more easily. Winston has reported success rates of roughly $70 \%$ at this site ${ }^{1}$-an encouraging figure in the light of other possible adverse factors such as the fertility of a new partner and the effects of increasing age. The Falope ring is another popular device, but occasional problems have been reported, including transection of the tube on application and sloughing of the loop enclosed within the ring with subsequent separation of the two ends. Successful microsurgical reversal has been described with this method, ${ }^{4}$ but it is destructive: $2 \mathrm{~cm}$ or more of tube is occluded within the ring, whereas the same result can be achieved by occluding 3-4 $\mathrm{mm}$ of tube using one of the proprietary clips.

The data on the incidence of regret after sterilisation ${ }^{5-7}$ and on women requesting reversal $^{8}$ strongly support the present tendency in Britain for sterilisation to be performed electively and not immediately after abortion or delivery, and for minimally destructive procedures to be used both for female sterilisation and for vasectomy. ${ }^{9}$ Gynaecologists need to be aware of the new techniques now available: those who prefer surgical transection should preferably use an operation (such as the Oxford or Uchida procedures) which limits the destruction of tissue.

1 Anonymous. Reliability and reversibility of female sterilisation. $\mathrm{Br} \mathrm{Med} \mathcal{F}$ 1978;ii:1734-5.

2 Winston RML. Reversibility of sterilisation. International Planned Parenthood Medical Bulletin 1978;12 (6):1.

3 McCann MF. International Fertility Research Program Conference Paper-Female Sterilisation. Series No 76. Triangle Park: NC, 1977.

4 Yoon IB, King TM, Parmley TH. A two-year experience with the Falope ring sterilisation procedure. Am $\mathcal{f}$ Obstet Gynecol 1977;127:109-12.

5 Alderman B. Women who regret sterilisation. Br Med $\mathcal{f} 1977 ; \mathrm{ii}: 766$.

6 Enoch MD, Jones K. Sterilisation: a review of 98 sterilised women. Br F Psychiatry 1975;127:583-7.

7 Winston RML. Why 103 women asked for reversal of sterilisation. Br Med F 1977;ii:305-7.

${ }^{8}$ Emens JM, Olive JE. Timing of female sterilisation. Br Med $\mathcal{f} 1978$;ii: 1126.

9 Yeates WK. A plea to all vasectomists. Br Med $\mathcal{F} 1979$;i:55.

\section{Use of antidepressants in schizophrenia}

Depressive symptoms are exceedingly common in all stages of schizophrenia but usually go unnoticed until the florid psychotic features have settled. They have been explained as a psychological reaction of the patient to his condition, a pharmacological sequel to neuroleptic treatment, ${ }^{1-3}$ and (more recently) an extrapyramidal side effect-akinesia. ${ }^{4}$

In a series of 37 patients closely observed for six months after discharge from hospital 20 had depression at some time, 10 of them when discharged from hospital and 10 during the succeeding months. ${ }^{5}$ Interestingly, symptoms improved as frequently in patients who received no antidepressants as in those who did. A lower incidence was reported in an open study of 284 patients with recent or chronic disease ${ }^{6} ; 6-25 \%$ had depression during the first year of maintenance treatment, depending on the subsample. A comprehensive review of other 